\title{
Depressed spaces as an instrument for transformation of urban areas
}

\author{
Valentina Kurochkina, ${ }^{1, *}$ \\ ${ }^{1}$ Moscow State University of Civil Engineering, 26, sh. Yaroslavskoe, 129337, Moscow, Russia
}

\begin{abstract}
Recently, more and more often urban abandoned and depressed spaces that were previously used as industrial facilities or temporarily used are becoming the sphere of architectural and landscape transformations. These territories can occupy a significant part of the city. This paper examines the features of the formation of urban planning systems, as well as the impact of depressed spaces on the quality of the urban environment. This paper studies such depressed spaces as abandoned industrial areas and objects of unfinished construction. The paper assesses the impact of depressed spaces, identifies criteria that reflect the nature, scale and features of their impact on the environment, on the safety and quality of the urban environment, as well as their role in the structure of the city as a whole. The principles and features of the formation of such urban depressed spaces, as well as the patterns of their development are revealed. The features of the formation of open public space of urban systems, as well as ways of transforming depressed spaces, aimed at increasing their social significance, integrating them into the general urban development, and improving the ecological and social situation are considered. The paper concludes that the problem of restoration of depressed spaces is very important and urgent today. The creation of a continuous urban tissue is impossible without the reorganization of such spaces, as well as the creation of an integral compositional, functional and communication urban planning system.
\end{abstract}

\section{Introduction}

The formation of a modern urban environment requires new approaches to the development of free and already built-up urban areas, based on the principles of their integrated development and unity, taking into account the features of building a highquality, safe urban environment with favorable living conditions for humans [1].

Depressed spaces, which were previously industrial, transport, agricultural or temporarily used objects, are increasingly becoming objects of architectural and landscape transformations of urban areas.

The term "depressed" in relation to territories and spaces was originally socio-economic in nature. The term "depressed" was applied to urban areas at the beginning of the last century $[2,3]$. At the same time, the characteristic features of such areas were determined:

\footnotetext{
*Corresponding author: kurochkina@mgsu.ru
} 
1. The transition of the production and resource base into the phase of a steady decline,

2. Strong and stable lag behind other territories in terms of the main socio-economic indicators (including a low level of economic development, a high level of unemployment)

3. Lack of opportunities for the formation of a new economic specialization.

There are several types of depressed regions - agro-industrial, mining (focal) and old industrial [4].

Today it is almost impossible to single out agro-industrial depressed regions in their pure form, since the agrarian sector does not occupy a leading place in terms of production in the economy of the overwhelming majority of regions of the Russian Federation [5].

The type of mining depressed regions includes localized resource-producing territories (mainly mining and timber processing) located in sparsely populated areas (it should be noted that this does not include large coal, old-developed regions that belong to the group of old industrial ones).

The type of old industrial regions includes the regions, the structure of the economy of which was formed at different stages of industrial development (from the end of the 19th century to the middle of the 20th century), and it was these territories that suffered the most during the transformation processes of the 1990s.

In Soviet times, industrial enterprises were built in specialized industrial zones, but gradual development led to the filling of such areas with residential buildings. Today it is not uncommon to find examples when old industrial zones, factories and production areas are not used for their intended purpose, or are barely used.

In Moscow, a large number of industrial territories are located within the city limits, which completely ceased their activities. This led to the appearance of depressed spaces, neglected and non-functioning (or poorly functioning) territories in the urban environment, which began to form the "rusty belt" of the city.

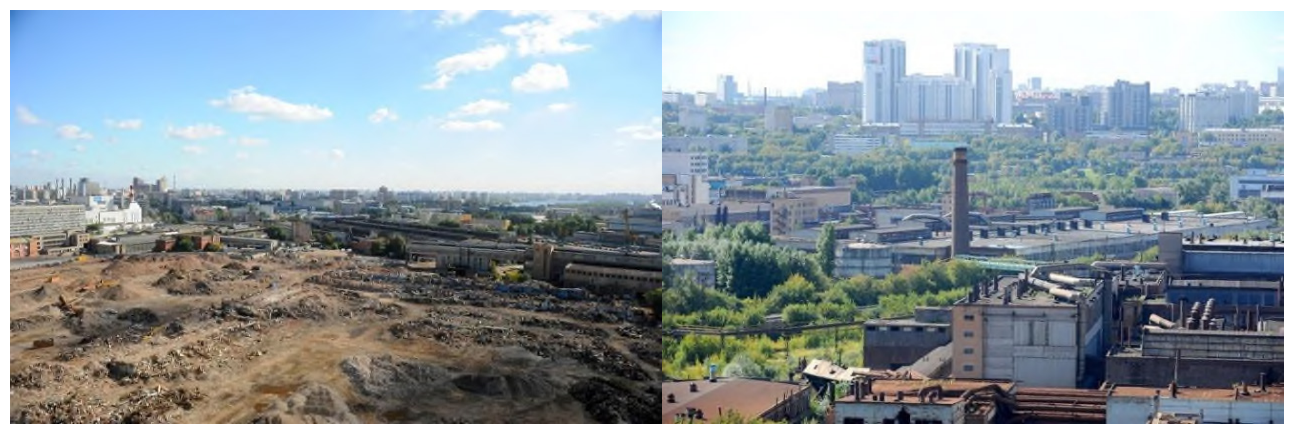

Fig. 1. Industrial territories as a factor in the formation of depressed spaces (https://stroi.mos.ru/renovaciya-promzon).

For example, in Moscow, they occupy about 18.8 thousand hectares, which is more than $17 \%$ of the territory of the old city (How Moscow's industrial zones will change // Electronic resource // URL: https://stroi.mos.ru/infographics/kak-izmieniatsia-promzonymoskvy). Thousands of hectares of so-called industrial zones, where many enterprises have ceased their activities, have retained their resources in an abandoned state. Such sites are landfills and warehouses with chaotic use and location. 


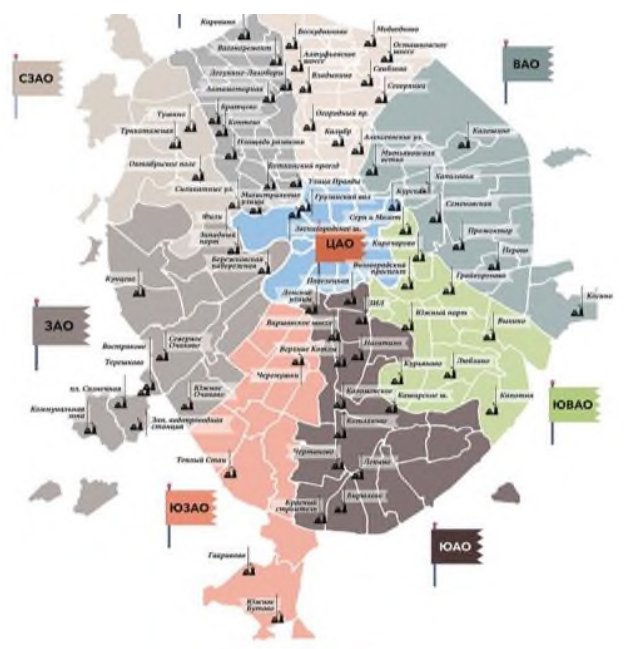

Fig. 2. Industrial zones of Moscow (https://stroi.mos.ru/infographics/kak-izmieniatsia-promzonymoskvy).

The reorganization of such territories will provide people with a high-quality, favorable and safe environment for living [6]. Nowadays, the subject areas of ongoing projects for the renovation of industrial territories cover three different directions of transformation of industrial territories from a functional point of view (Fig. 3).

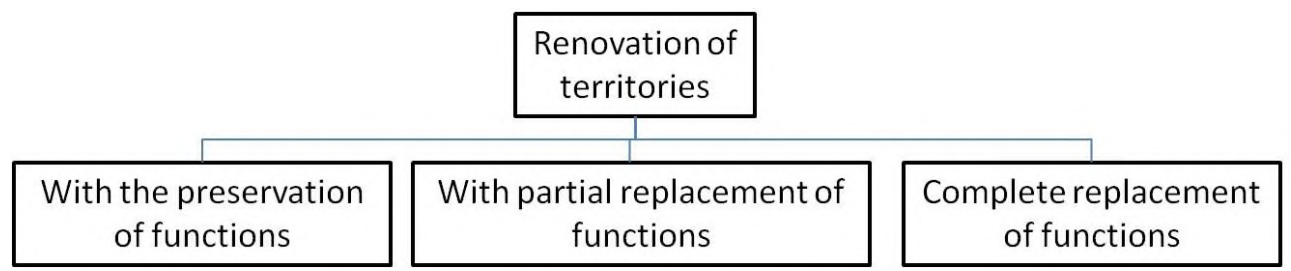

Fig. 3. Territory transformation models.

Such an integrated approach can contribute to the formation of an aesthetically complete environment, the construction of architecturally significant public facilities, as a place of social activity in the city and places of intensive recreation. The renewal of these urban areas is based on the formation of an integrated urban development with housing, social facilities and new jobs.

This is evidenced by striking examples of European industrial zones. In New York, for example, the famous Highline Industrial Park appeared on the site of a dilapidated railway. In London, the abandoned dock area has been turned into a popular Contemporary Art Center. In Paris, former train stations and old factories have long been used for art and media clusters.

Center for Arts and Media Technology in Karlsruhe (Germany). In 1997, the placement of a modern public center on the territory and in the buildings of the industrial enterprise "IKWA-Karlsruhe-Augsburg" was one of the examples of a radical revision of the role of an industrial facility in the renewal of the urban landscape [7]. The wide, three-storey blocks of the factory building are symmetrically arranged around ten courtyards. The building is made of concrete frames filled with brickwork along the facades. Abandoned in the seventies and then occupied by artists, the building eventually obtained the title of industrial architectural monument $[8,9]$. Another project for the transformation of the port of Hamburg is considered the largest urban territory reconstruction project in Europe in 
terms of area. Apart from the water surface, the architectural and landscape transformations affected an area of about 220 hectares (Fig. 2).

With the formation of the European Union, the turnover of the port of Hamburg has noticeably decreased. The subsequent strengthening of border security measures led to a further decrease in freight traffic. Despite the fact that Hamburg remains the second largest container port in Europe after Rotterdam, the city authorities decided to revitalize this territory (HafenCity - die Genese einer Idee// Electronic resource// URL: https://www.hafencity.com/de/ueberblick/hafencity-die-genese-einer-idee.html (access date: 23.10 .2020$)$ ).

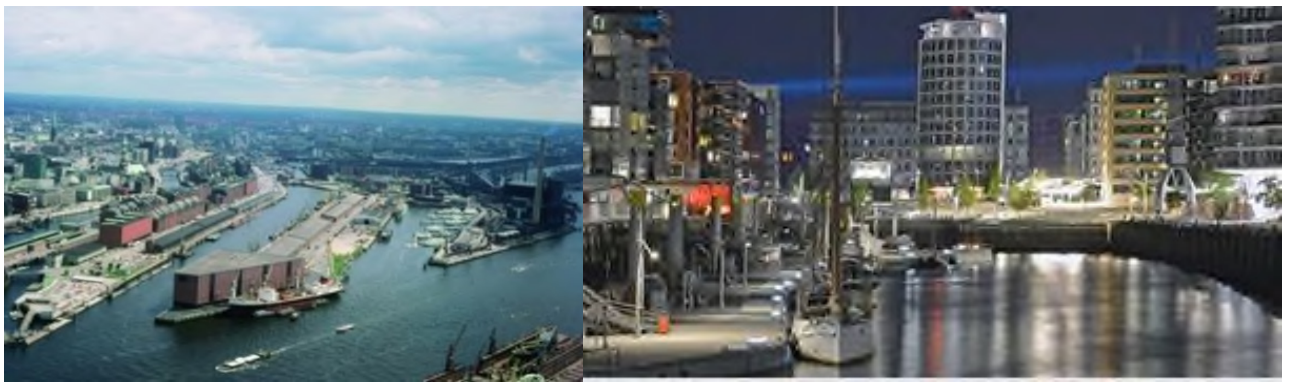

Fig. 4. HafenCity Hamburg (Hamburg, Germany): left - early 90s, right - our days (https://www.hafencity.com/de/ueberblick/hafencity-die-genese-einer-idee.html).

The project began in June 2001. According to the project, the new district of the city should include 10 new isolated quarters, increasing the central part of the city by $40 \%$ (Fig. 4). One of the main attractions of the new district is the Herzog \& de Meuron's philharmonic concert hall. The building consists of 2 parts: the lower part is a historic brick building, where were warehouses; the upper one is a new volume in which the philharmonic hall is located (Fig. 5).

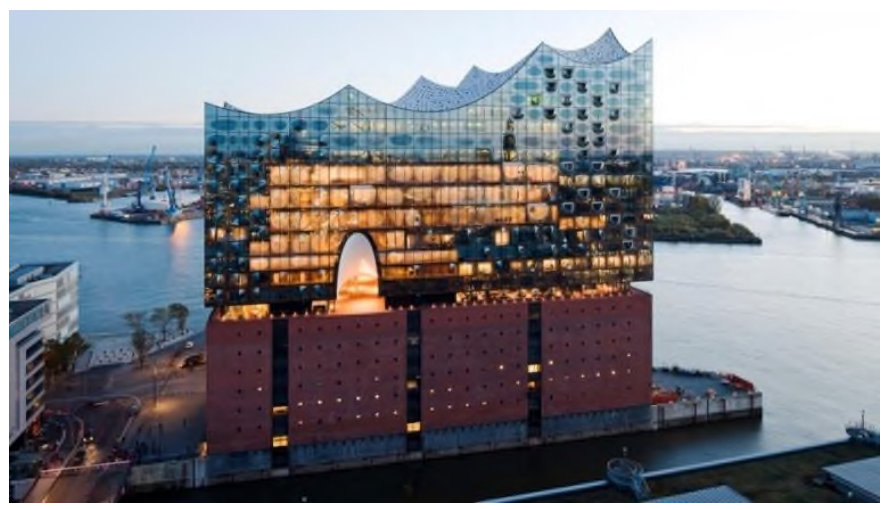

Fig. 5. The Herzog \& de Meuron's philharmonic concert hall. Outside view.

(https://www.fsbna.com/us/inspirations/projects/elbe-philharmonic-hall-hamburg/).

In addition to concert halls, the building houses a five-star hotel, residential apartments, a restaurant, fitness centers and conference rooms. At the junction of these two parts, a public space with open terraces and observation platforms, where anyone can get, has emerged. On this floor, there are also bars, restaurants, souvenir shops, ticket offices and the entrance to the Philharmonic Hall. 


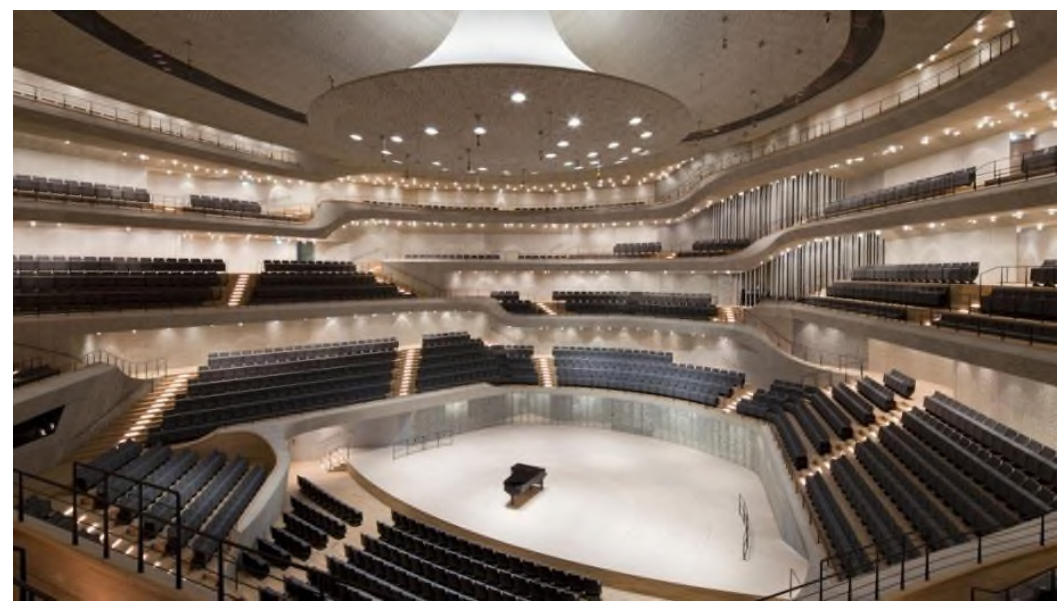

Fig. 6. The Herzog \& de Meuron's philharmonic concert hall. Inside view (https://www.fsbna.com/us/inspirations/projects/elbe-philharmonic-hall-hamburg/).

It is obvious that the involvement of territories from among inefficiently used areas, mainly depressed spaces, will provide a qualitative increase in the attractiveness of the city. The application of the principles of such an integrated development of urban areas in Russia can become a tool for improving safety, comfort and quality of the environment. This, in turn, will ensure the integrity and sustainable development of the territories, which will ensure the transition of Russian cities to modern development models.

\section{Materials and methods}

Since there is a long-term decline in environmental quality indicators in depressed spaces, the term "depressed" is increasingly used in relation to spaces in urban planning and ecology. The scale of depressed spaces can vary significantly. On this basis, they can be divided into several types:

1. regional - parts of territories, regions, republics or individual cities;

2. district - parts of the territory of cities, settlements or urbanized areas;

3. local - depressed objects as separate abandoned buildings or a complex of buildings and territories around them.

Despite the fact that depressed territories have sufficient economic potential, but, as a result of the structural crisis, characterized by a steady decline in production and real incomes of the population, growing unemployment, they do not have the conditions for independent resolution of the current crisis situation [3].

Unclaimed abandoned buildings appear in such territories, which, at the same time, may be of historical value. 


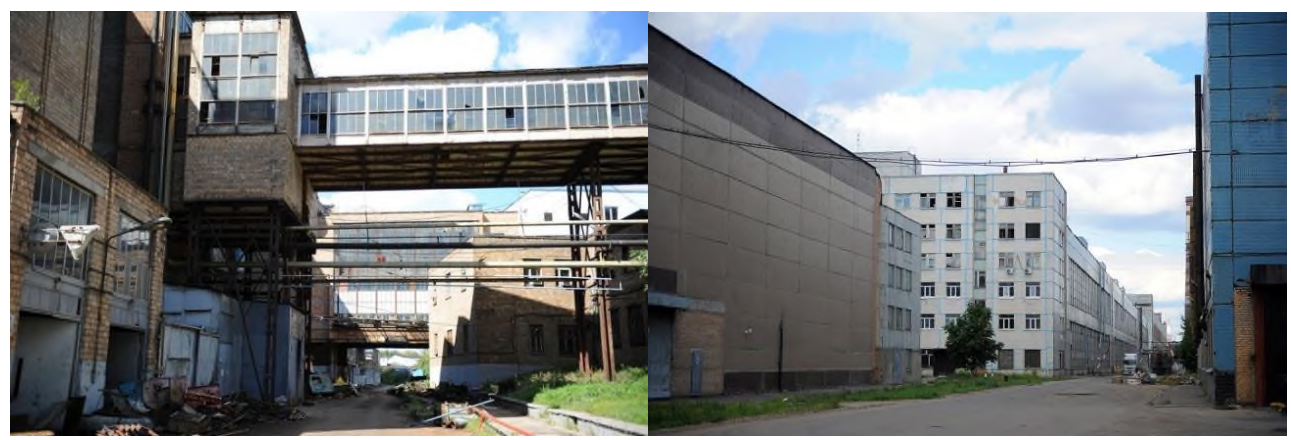

Fig. 7. Abandoned structures in industrial areas (https://stroi.mos.ru/renovaciya-promzon).

The signs of "depression" include: the presence on the territory of abandoned, destroyed or dilapidated structures with varying degrees of moral and physical deterioration. Such depressed spaces can also include dilapidated low-rise housing stock, disturbed or empty areas, etc.

\section{Research results}

Since there is a long-term decline in environmental quality indicators in such spaces, the term "depressed" is increasingly used in relation to spaces in urban planning and ecology.

In the conditions of urban development, one can often find objects of unfinished construction. Incomplete construction structures are: 1. real estate objects built, but not put into operation, 2. objects on which work is underway (but they were not completed on time according to the schedule), or 3. objects whose construction has been stopped or stalled. The latter (stalled) include on hold objects or objects with stalled construction. If the construction of objects with stalled or stopped construction is not resumed for a long time, then such objects of unfinished construction also acquire the property of "depression". In some cases, construction work on unfinished objects has not been carried out for many years. Such buildings and structures [10] are gradually collapsing, and the area allotted for their construction turns into a territory, which can often pose a danger to human life, especially for children and adolescents $[11,12,13]$. Table 1 shows the classification $[14,16]$ supplemented by the author.

Table 1. Types of unfinished construction objects, their characteristic technical condition and geoecological consequences of existence.

\begin{tabular}{|l|l|l|l|}
\hline \multicolumn{1}{|c|}{$\begin{array}{c}\text { Type of } \\
\text { unfinished object }\end{array}$} & \multicolumn{1}{|c|}{$\begin{array}{c}\text { Work } \\
\text { stoppage } \\
\text { period }\end{array}$} & $\begin{array}{l}\text { Characteristic } \\
\text { technical condition }\end{array}$ & \multicolumn{1}{|c|}{ Geoecological consequences } \\
\hline $\begin{array}{l}\text { Under } \\
\text { construction }\end{array}$ & 0 & $\begin{array}{l}\text { Suitable for the } \\
\text { nature of ongoing } \\
\text { construction work }\end{array}$ & $\begin{array}{l}\text { Converting an urban area into a } \\
\text { construction site }\end{array}$ \\
\hline $\begin{array}{l}\text { with temporarily } \\
\text { stalled or } \\
\text { terminated } \\
\text { construction }\end{array}$ & $\begin{array}{l}\text { less than } \\
\text { months }\end{array}$ & $\begin{array}{l}\text { Elimination and } \\
\text { destruction of part of } \\
\text { the construction } \\
\text { infrastructure }\end{array}$ & $\begin{array}{l}\text { The appearance of synanthropic } \\
\text { organisms on the site, its littering }\end{array}$ \\
\hline $\begin{array}{l}\text { with temporarily } \\
\text { stalled } \\
\text { terminated or } \\
\text { construction }\end{array}$ & 6 months -1 & $\begin{array}{l}\text { Deterioration of } \\
\text { interior materials }\end{array}$ & $\begin{array}{l}\text { The constant presence of } \\
\text { synanthropic organisms on the } \\
\text { site, the appearance of illegal } \\
\text { dumps }\end{array}$ \\
\hline $\begin{array}{l}\text { with temporarily } \\
\text { stalled year }\end{array}$ & $\begin{array}{l}1 \text { year }-3 \\
\text { years }\end{array}$ & $\begin{array}{l}\text { Destruction of } \\
\text { cladding and site }\end{array}$ & $\begin{array}{l}\text { Gradual overgrowing of the site, } \\
\text { turning it into uncontrollable }\end{array}$ \\
\hline
\end{tabular}




\section{ERSME-2020}

\begin{tabular}{|c|c|c|c|}
\hline $\begin{array}{l}\text { terminated } \\
\text { construction }\end{array}$ & & infrastructure & $\begin{array}{llll}\begin{array}{l}\text { natural and technical } \\
\text { (NTS) }\end{array} & & \\
\end{array}$ \\
\hline $\begin{array}{l}\text { with temporarily } \\
\text { stalled or } \\
\text { terminated } \\
\text { construction }\end{array}$ & $3-5$ years & $\begin{array}{l}\text { Destruction of } \\
\text { building structures }\end{array}$ & $\begin{array}{l}\text { Conversion of the adjacent } \\
\text { territory into uncontrollable NTS. } \\
\text { Development of dangerous } \\
\text { geological processes and } \\
\text { phenomena }\end{array}$ \\
\hline $\begin{array}{l}\text { with temporarily } \\
\text { stalled or } \\
\text { terminated } \\
\text { construction }\end{array}$ & $\begin{array}{l}\text { more than } 5 \\
\text { years }\end{array}$ & $\begin{array}{l}\text { Destruction of } \\
\text { building structures } \\
\text { beyond repair }\end{array}$ & $\begin{array}{l}\text { Conversion of the adjacent } \\
\text { territory into uncontrollable NTS, } \\
\text { temporary illegal settlement of } \\
\text { people. } \\
\begin{array}{l}\text { Development of dangerous } \\
\text { geological processes and } \\
\text { phenomena }\end{array}\end{array}$ \\
\hline
\end{tabular}

Although such structures, both from a legal point of view and from the point of terminology, do not strictly fit the definition of "depressed", nevertheless, they are inherently depressed spaces, which are also characterized by a decrease in environmental quality indicators. Therefore, we will classify them as "conditionally depressed" or "potentially depressed" spaces.

Such a decrease in environmental quality indicators is associated with a negative technogenic impact on the environment of unfinished construction objects. It is a fact that the nature (mechanism) of technogenic impact can be divided into physical, physicochemical, chemical and biological.

Table 2 shows the type of technogenic impact of the objects of unfinished construction.

Table 2. Types of technogenic impact of the objects of unfinished construction on the environment.

\begin{tabular}{|c|c|c|}
\hline $\begin{array}{c}\text { Class, subclass of } \\
\text { technogenic } \\
\text { impacts } \\
\end{array}$ & Type of impact & Potential sources of impact \\
\hline \multirow{12}{*}{ Physical impact } & Static gravitational & Building, construction \\
\hline & Statistical load & Pits, slopes, cavities \\
\hline & Dynamic load & Explosions \\
\hline & Explosive destruction & Explosions \\
\hline & Construction planning - terrain change & All stages of construction \\
\hline & Digging pits, channels & Pits, channels \\
\hline & Slope trimming & Pits, channels \\
\hline & Subsidence-suffusion impact & Underground leaching \\
\hline & Flooding & Leaks, change in groundwater level \\
\hline & Convective & Solution injection \\
\hline & Destruction & Fire \\
\hline & Thermal impact & Fires \\
\hline \multirow{3}{*}{$\begin{array}{l}\text { Physicochemical } \\
\text { impact }\end{array}$} & Diffuse (direct) & Groundwater, buildings, structures \\
\hline & Toxic hazardous substances, gas-air mixtures & Explosions \\
\hline & Toxic hazardous substances, gas-air mixtures & Fire \\
\hline \multirow{2}{*}{ Biological impact } & Bacteriological & $\begin{array}{l}\text { Building, structure, construction } \\
\text { waste, landfills }\end{array}$ \\
\hline & Microbiological & $\begin{array}{l}\text { Building, structure, construction } \\
\text { waste, landfills }\end{array}$ \\
\hline \multirow{3}{*}{ Chemical impact } & Heavy metals, acidic, alkaline, etc. & $\begin{array}{l}\text { Building, structure, construction } \\
\text { waste, landfills }\end{array}$ \\
\hline & $\begin{array}{llll}\begin{array}{l}\text { Environmental } \\
\text { substances }\end{array} & \text { pollution } & \text { with } & \text { toxic } \\
\end{array}$ & Explosions \\
\hline & $\begin{array}{l}\begin{array}{l}\text { Environmental pollution } \\
\text { substances }\end{array} \\
\text { with }\end{array}$ & Fire \\
\hline
\end{tabular}

It can be seen from the tables above that unfinished construction is a source of a strong negative technogenic impact on the environment, which are very multifaceted and diverse 
in nature. For example, the spread of contaminants during the depressurization of containers intended for storing liquid materials on abandoned construction sites and the multiplication of blood-sucking mosquitoes in flooded underground premises.

In relation to hazardous natural and man-made processes, the concepts of "hazard" $(\lambda)$, "risk" $\left(r_{a}\right)$ and "vulnerability" (v) are used:

$$
\mathrm{r}_{\mathrm{a}=} \lambda^{*} \mathrm{v}
$$

where: $r_{a}$ - risk of an event occurring - the possibility that human actions or the result of its activities will lead to consequences that affect human values (for example, an accident),

$\lambda$ - event hazard ratio;

$\mathrm{v}$ - vulnerability factor of a target object.

The main groups of risks associated with unfinished construction and measures to reduce them are shown in Table 3.

Table 3. The main groups of risks associated with unfinished construction and measures to reduce them.

\begin{tabular}{|c|c|c|c|}
\hline Groups of risks & Nature of risk & Risks & Risk mitigation measures \\
\hline $\begin{array}{l}\text { Risks of constant } \\
\text { physical impact }\end{array}$ & $\begin{array}{l}\text { Mechanical impact in the } \\
\text { absence of accidents at the } \\
\text { facility }\end{array}$ & $\begin{array}{l}\text {-Violations of the } \\
\text { integrity of structures } \\
\text {-Development } \\
\text { landslide processes } \\
\text {-Fire breakouts }\end{array}$ & $\begin{array}{l}\text { Environmental engineering } \\
\text { of the facility }\end{array}$ \\
\hline $\begin{array}{l}\text { Risks of constant } \\
\text { physicochemical } \\
\text { impact }\end{array}$ & Physicochemical effects & $\begin{array}{l}\text {-Fire breakouts } \\
\text {-Explosion breakouts }\end{array}$ & $\begin{array}{l}\text { Environmental engineering } \\
\text { of the facility }\end{array}$ \\
\hline $\begin{array}{l}\text { Risks of } \\
\text { permanent } \\
\text { biological impact }\end{array}$ & $\begin{array}{l}\text { Dissemination of unwanted } \\
\text { organisms and pathogens } \\
\text { from the site }\end{array}$ & $\begin{array}{l}\text { Development of the } \\
\text { pathogenic environment }\end{array}$ & $\begin{array}{l}\text { Periodic measures for the } \\
\text { destruction of unwanted } \\
\text { organisms and their } \\
\text { habitats }\end{array}$ \\
\hline $\begin{array}{l}\text { Risks of constant } \\
\text { chemical impact }\end{array}$ & $\begin{array}{l}\text { Chemical impact in the } \\
\text { absence of exposure to the } \\
\text { object }\end{array}$ & $\begin{array}{l}\text {-Soil contamination } \\
\text {-Pollution } \\
\text { groundwater } \\
\text {-Fire breakouts } \\
\text {-Explosion breakouts }\end{array}$ & $\begin{array}{l}\text { Environmental engineering } \\
\text { of the facility }\end{array}$ \\
\hline
\end{tabular}

The existence of unfinished construction objects can worsen the ecological conditions of the urban environment at a considerable distance from their locations [15]. Therefore, it is possible to distinguish intra-system and external risks associated with objects of unfinished construction (Table 4)

Table 4. Intra-system and external risks associated with unfinished construction and measures to reduce them.

\begin{tabular}{|l|l|l|}
\hline \multicolumn{1}{|c|}{ Groups of risks } & \multicolumn{1}{|c|}{ Nature of risk } & \multicolumn{2}{|c|}{ Risk mitigation measures } \\
\hline $\begin{array}{l}\text { Risks of impacts in the } \\
\text { event of technogenic } \\
\text { emergencies at the } \\
\text { facility }\end{array}$ & $\begin{array}{l}\text { Negative environmental impacts in } \\
\text { the event of a fire and other accidents } \\
\text { at the facility }\end{array}$ & $\begin{array}{l}\text { Elimination } \\
\text { accumulations of fire } \\
\text { hazardous materials and } \\
\text { other sources of emergency } \\
\text { situations }\end{array}$ \\
\hline $\begin{array}{l}\text { Risks of impacts in the } \\
\text { event of various types of } \\
\text { emergencies outside the } \\
\text { facility }\end{array}$ & $\begin{array}{l}\text { External factors contributing to the } \\
\text { spread of negative environmental } \\
\text { impacts from the facility }\end{array}$ & $\begin{array}{l}\text { Creation and maintenance } \\
\text { of barriers in working order } \\
\text { that prevent the influence of } \\
\text { external factors on the } \\
\text { object }\end{array}$ \\
\hline
\end{tabular}

With the resumption of work on unfinished construction facilities, especially with the demolition of dilapidated structures, the risks of such phenomena may increase. For this reason, solving the problem of long-term construction requires a comprehensive approach. 
When organizing work on the completion or demolition of unfinished objects within the framework of a unified work program, measures should also be provided to prevent or minimize the negative geoecological consequences of the planned activity.

The identification of "depressed" and "potentially depressed" spaces in the urban tissue requires the determination of qualitative parameters, such as the localization of zones of impact of depressive spaces, their parameters and properties.

Recently, projects aimed at the restoration of such territories have been widely implemented. So, for example, in Moscow, 61 projects for planning a territory with a total area of about 3.4 thousand hectares with a construction potential of more than 31 million square meters were approved in 2011-2016. Today, 17 approved projects are already being implemented, 40 more are in development. The most significant territories of industrial zones that are in the active stage of implementation are: Likhachev plant ("ZIL"), the territory of the former Tushino airfield, OJSC Moscow Metallurgical Plant "Hammer and Sickle", the territory of the former Moscow Mirror Plant and others. Nevertheless, in general today, if we talk not only about Moscow, but also about many cities of Russia, it would probably be fair to say that there is a shortage of open public spaces, including "open green spaces".

At the same time, the correct organization of public spaces can often be a solution to environmental problems. An example is the Queen Elizabeth Olympic Park. This park was created as part of a program to transform industrial zones along the Thames (Fig. 8).

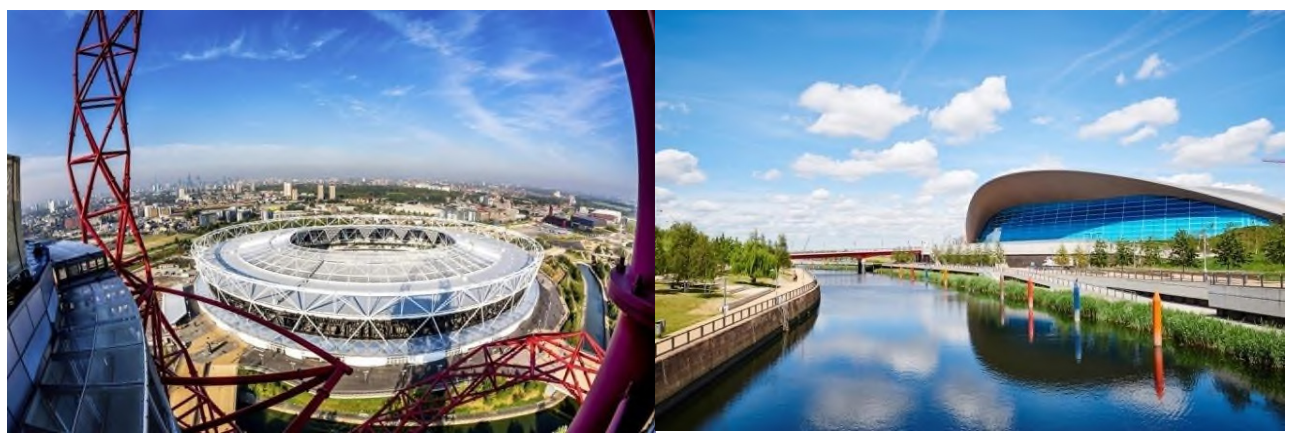

Fig. 8. Queen Elizabeth Olympic park (United Kingdom)

(https://www.queenelizabetholympicpark.co.uk/).

An industrial zone used to be located on the site of Queen Elizabeth Olympic park, which previously led to severe pollution of the atmosphere, water resources and soils of the adjacent territories. Therefore, before the establishment of the park, significant work was carried out to clean up soil and water using modern technologies.

\section{Conclusions}

Improving the safety and quality of the urban environment, as well as increasing the efficiency of using the urban planning potential of territories, is impossible without the restoration of urban depressed spaces. The need to restore such territories, disclose their new opportunities, taking into account modern requirements, increase their social functions, integrate them into the general urban development and the formation of a single and fullfledged urban environment (including through the construction of open public spaces) becomes absolutely obvious.

The recreational potential of such territories is used very little, which greatly impoverishes the functional, socio-cultural and spatial functions of the urban center and peripheral areas. The main direction of development of territories from among ineffectively 
used areas, including depressed spaces, is to increase their urban planning role and the formation of new zones of urban activity, for example, through the formation of open public spaces, including "green open spaces" through the creation of viewpoints, green areas (parks, squares, boulevards and arboretums), iconic architectural complexes.

The goal of implementing the transformations of depressed areas should be the formation of favorable living conditions, improving the quality and safety of the urban environment as a whole, and therefore increasing the investment attractiveness of both individual districts and the entire city as a whole.

\section{References}

1. V.I. Telichenko, V.A. Kurochkina, B.L. Kirov, Ecology of urban areas 3, 32-39 (2016)

2. G.I. Mansurova, Depressive regions: basic concepts and reasons of transition to the depression 69, 65-68 (2015)

3. M.N. Tolchinskaja, Regional problems of economic transformation 4(17), 3-3 (2008)

4. A.G. Granberg, The foundations of regional economy (HSE Publ., Moscow, 2000)

5. S.A. Surkova, V.V. Shusharin, Economics and management 1(94), 25-37 (2009)

6. V.I. Telichenko, Proceedings of Moscow State University of Civil Engineering 1(15), 1-1 (2020)

7. A.N. Fedan, News of KSUAE 3(45), 88-96 (2018)

8. M.A. Zolotyh, StudArctic Forum 2(6), 33-46 (2017)

9. M.A. Andreev, Renovation of industrial territories and objects, https://elima.ru/articles/?id=13

10. A. Mottaeva, As. Mottaeva, EMMFT 2019, AISC 1258, 506-517 (2021) https://doi.org/10.1007/978-3-030-57450-5_44

11. C. Ross, J. Mirowsky, Journal of Health and Social Behavior 42(3), 258-276 (2001)

12. J.M. Shane, Problem-Oriented Guides for Police. Problem-Specific Guides Series 64, 1-69 (2012)

13. E. Ganebnykh, T. Burtseva, A. Petuhova, A. Mottaeva, E3S Web of Conferences 91, 08035 (2019) doi.org/10.1051/e3sconf /20199108035

14. V.A. Kurochkina, I.Y. Yakovleva, The Eurasian Scientific Journal 4(12), 1-8 (2020)

15. A.L. Suzdaleva, Ecology of Urban Areas 2, 12-16 (2014)

16. Kovačič, B., Kamnik, R. Procedia Engineering. 2016. 165. Pp. 918-925. DOI:10.1016/j.proeng.2016.11.801

17. D. Beliaev, et al. E3S Web of Conferences 164, 06029 (2020) doi:10.1051/e3sconf/202016406029 